\title{
Systemic Mastocytosis
}

National Cancer Institute

\section{Source}

National Cancer Institute. Systemic Mastocytosis. NCI Thesaurus. Code C9235.

A variant of mastocytosis characterized by multifocal, dense infiltrates of mast cells (15

or more mast cells in aggregates) detected in the bone marrow and/or other

extracutaneous sites. (WHO, 2001) -- 2003 